\title{
Analysis of Manpower Planning Based on Digital Economy in Cianjur Regency
}

\author{
Gatiningsih \\ Institut Pemerintahan Dalam Negeri (IPDN), Indonesia \\ Email: gatiningsih@ipdn.ac.id
}

\begin{abstract}
There are three main characteristics of labor problems in Indonesia: First, the high growth rate of the workforce due to the rapid flow of population growth entering the working age. Second, the number of the labor force is large, but the average has low education, and third, the labor force participation rate is high, but the average income of workers is low. This research uses qualitative methods with a descriptive analysis approach. The study was conducted in the Cianjur Regency area. Analysis of current and future employment conditions through quantitative descriptive analysis methods assisted by statistical tools. For this reason, the data used in the framework of this study are Susenas data. This research shows that the low quality of the population is a barrier to economic development. This is mainly due to the low level of education and knowledge of the workforce. The economy of Cianjur Regency in 2020 grew by $7.35 \%$, and employment growth by $4.84 \%$, with an elasticity of 0.6585 . So that the number of job opportunities in 2015 was 354,201 people. Meanwhile, the economic forecast for Cianjur Regency in 2020 will grow by $7.72 \%$ and employment growth by $4.14 \%$, with an employment elasticity of 0.5363 . It is estimated that GRDP at the constant price of Cianjur Regency is Rp. 10,012.91 billion, and job opportunities created as many as 438,490 people.
\end{abstract}

Keywords: Manpower Planning, Digital Economy, Cianjur Regency.

\section{A. INTRODUCTION}

The main target of human resources development is creating new jobs, accompanied by increased productivity and reduction of underemployment (Abdurakhmanova, 2020). The 2020 National Labor Force Survey results noted that the number of the labor force in Indonesia in 2020 is estimated to reach 105.8 million people with an open unemployment rate of 10.3 percent or around 10.9 million people. The percentage of workers who were working in part (underemployment) reached 31.0 percent. The available unemployment rate in the Cianjur district increased from 4.78 percent in 2020 to 10.21 percent in 2020. The number of open unemployment in 2020 is estimated to reach 198,881 people, and the percentage of underemployment is 35.2 percent.

Human resources planning can be done through the supply side and the demand side. From the supply side, workforce planning tends to discuss potential workforce or planning issues regarding people who will become newcomers to the workforce group. In the end, this plan will discuss more the number and quality of the workforce (Asai, Hayashi \& Minazuki, 2011).

In 2020 there were 131,016 people in the workforce in Cianjur Regency, while in the previous year, the number of sea unemployment was 105,125 people. In 2020 the labor force or labor supply experienced an average growth of 1.39 percent per 
year; the growth rate of employment opportunities in the same period was minus 0.57 percent per year. The low rate of change in the demand for labor compared to the growth in labor supply has resulted in a higher increase for those looking for work (Bakry, 2004). The average growth of the working-age population looking for a job is 30.60 percent per year during the 2017-2020 period. This means the Cianjur poverty line is Rp. 371,699 per capita per month.

The high unemployment rate in Cianjur Regency is caused by an imbalance between supply and demand for the labor force and a mismatch between the skills or education of a job seeker and market needs. Based on data from the Cianjur Regency Manpower Office, in 2020, there were 4,181 registered job seekers and 1,006 registered job vacancies. Meanwhile, there are only 616 people who can fill in the placement of workers or job vacancies. This proves that the Cianjur district also experiences dualism in the labor market. On the one hand, there is an excess supply (labor surplus); on the other hand, there is excess demand which is caused by the low level of education and the ability to produce job seekers in the Cianjur district, especially job seekers registered with the Cianjur Regency Manpower Office in 2020.

The low quality of the population is also a barrier to a country's economic development (Bashehab, 2013). This is due to the low level of education and knowledge of the workforce (Chao-he, 2006). Therefore, with the development of the economy, especially industry, it is clear that more skilled workers are needed (Etim, Ibietan \& Abasilim, 2020). In creating job opportunities, various policies that promote the investment climate, including the workforce climate, still need to be improved (Etoundi, Onana, Olle \& Eteme, 2016). One of the efforts that can be made to reduce the number of open unemployment is to encourage investment to provide the broadest possible job opportunities for the unemployed (Hojeghan \& Esfangareh, 2011).

Considering that investment is an essential factor for regional economic development, regional government policies in creating a conducive and attractive investment climate are prerequisites for the development of various economic activities that can absorb labor and reduce unemployment (Jin, Gao \& Wang, 2019). Therefore, local governments must overcome the weak points of investment that are often complained of by the business world, including issues of licensing, taxation, customs, legal certainty, inhibiting local regulations, infrastructure, and the labor climate (Li, Nucciarelli, Roden \& Graham, 2016). The speed in fixing the investment climate greatly determines the investment response to the intense competition between countries in attracting investment to create job opportunities ( $\mathrm{Li}, \mathrm{Cao} \&$ Luo, 2020).

This topic is important to research because Indonesia is currently transitioning from a traditional economy to a digital economy era. The era of the conventional economy was an era before information technology developed rapidly (Malisuwan, Tiamnara \& Suriyakri, 2016). In the conventional economic period, trading of funds or other transactions between communities was carried out directly (Manski, 2000). This kind of transaction requires that the transacting parties be 
physically present at the same time and place. In contrast to the digital economy era, the transactions previously described can be carried out with the help of information and communication technology, thereby emerging a new generation known as the Digital Economy Era (Mutula \& Van Brakel, 2007).

A few decades ago, the advent of the internet had revolutionized the way the world works at such a rapid pace. Information flows so fast, even in real-time (Sanchez \& Correia, 2018). The speed of information makes time seem to cut, and this world is like experiencing a time leap. On the one hand, the development of technology is so unique and brings tremendous benefits to the advancement of human civilization (Parka, Yeonb \& Kimc, 2006). The types of work that previously required a relatively large physical level are now somewhat able to be replaced by automatic machines as if technology has been able to shift the position of the human brain's ability in various human sciences and activities (Rahmana \& Senusia, 2019). Technological advances have now honestly been recognized and are felt to provide a lot of convenience and comfort for humanity.

\section{B. METHOD}

This research uses qualitative methods with a descriptive analysis approach. The study was conducted in the Cianjur Regency area. Analysis of current and future employment conditions through quantitative descriptive analysis methods assisted by statistical tools. For this reason, the data used in the framework of this study are Susenas data.

\section{RESULT AND DISCUSSION}

The working-age population in Cianjur Regency in 2020 is estimated to be 717,500 people consisting of a workforce of 362,505 people and not a force of 354,995 people. If the average growth of the working-age population in the next five years in Cianjur Regency is estimated at $4.19 \%$ annually, then the number of the working-age population in Cianjur Regency in 2021 is estimated to be 881,116 people consisting of a workforce of 446,300 people and non-generation. Work as many as 434,816 people. For more details about the estimated development of the working-age population in the Cianjur Regency, see table 1.

Table 1 Estimated Employment Opportunities, Labor Force, Non-Labor Force, Unemployment and Population in Cianjur Regency in 2016-2020

\begin{tabular}{|l|c|c|c|c|c|c|}
\hline \multicolumn{1}{|c|}{ SECTOR } & $\mathbf{2 0 1 5}$ & $\mathbf{2 0 1 6}$ & $\mathbf{2 0 1 7}$ & $\mathbf{2 0 1 8}$ & $\mathbf{2 0 1 9}$ & $\mathbf{2 0 2 0}$ \\
\hline Agriculture & 237.568 & $\mathbf{2 4 4 . 6 9 4}$ & 251.423 & 257.960 & 264.389 & 270.622 \\
\hline Mining & 789 & 858 & 924 & 985 & 1.070 & 1.152 \\
\hline Industry & 29.558 & 34.169 & 39.293 & 44.793 & 50.839 & 57.446 \\
\hline Electricity & 480 & 528 & 581 & 638 & 693 & 763 \\
\hline Building & 3.379 & 3.581 & 3.778 & 3.966 & 4.144 & 4.400 \\
\hline Trading & 44.807 & 47.496 & 50.207 & 52.462 & 54.556 & 56.865 \\
\hline Transport & 15.302 & 16.229 & 17.161 & 18.148 & 19.055 & 19.959 \\
\hline
\end{tabular}




\begin{tabular}{|l|c|c|c|c|c|c|}
\hline $\begin{array}{l}\text { Finance and } \\
\text { Banks }\end{array}$ & 330 & 334 & 349 & 364 & 386 & 408 \\
\hline Services & 22.142 & 23.139 & 24.122 & 25.087 & 26.078 & 27.056 \\
\hline $\begin{array}{l}\text { Employment } \\
\text { Opportunity }\end{array}$ & 354.203 & 370.967 & 387.678 & 404.254 & 421.079 & 438.690 \\
\hline Workforce & 363.505 & 379.280 & 395.786 & 412.243 & 428.903 & 446.400 \\
\hline $\begin{array}{l}\text { Not the Labor } \\
\text { Force }\end{array}$ & 354.996 & 370.979 & 386.560 & 402.022 & 418.495 & 434.826 \\
\hline Searching job & 8.404 & 8.225 & 8.200 & 7.980 & 7.835 & 7.820 \\
\hline $\begin{array}{l}\text { Hidden } \\
\text { Unemployment }\end{array}$ & 63.766 & 63.074 & 62.038 & 60.648 & 58.961 & 57.005 \\
\hline Population & 739.968 & 773.405 & 792.966 & 822.394 & 855.767 & 897.867 \\
\hline
\end{tabular}

Source: Projection Figures

The supply of labor has increased quite rapidly during the 2015-2020 period with a growth rate of around 3.06 percent per year during the 2015-2020 period and 2.50 percent per year for the 2015-2020 period. Meanwhile, the growth rate of labor demand tends to be smaller, only 2.82 percent per year in the 2015-2020 period and 2.39 percent per year for the 2015-2020 period. The imbalance between the development of supply and the demand for labor during the 2015-2020 period resulted in a significant increase in the number of unemployed. The unemployment rate increased from 1.06 percent in 2015 to 2.88 percent in 2015 and 4.78 percent in 2020.

Meanwhile, if the economic growth of the Cianjur regency for the 2015-2020 period does not experience a significant improvement from the 2015-2020 period, then the growth rate of labor demand will also be lower. It is estimated that it could reach 1.73 percent per year. At this stage, the open unemployment rate for 2015-2020 can go 10.59 percent to 14.57 percent or with the number of unemployed ranging from 63,766 people to 57,005 people. Conversely, if there is a better economic development with a growth rate of more than 6.00 percent per year during the 20152020 period, the number and rate of unemployment in Cianjur Regency will be smaller than expected.

Most workforce needs, especially in the agricultural sector, are of elementary school educational background and below. For sector $\mathrm{M}$, although it is slightly better than sector A, more than half of those who work in this sector also have primary school education or below. More highly educated workers (SLTA and above) are needed in the S sector. In 2017, around 49.17 percent of the S sector workforce required high school education and above. Judging from the level of education completed by workers, sector A is the sector that has the least good resources among the three industries analyzed. According to the main employment sector during the 2015-2020 period, the development of labor demand shows that the agricultural sector remains the most dominant sector in absorbing labor, although its contribution tends to decline. 


\section{Estimated Job Opportunities}

Job opportunities are the many job opportunities available that can absorb people who work in various economic activities. It is estimated that the economy of Cianjur Regency in 2015 grew by $7.35 \%$, and employment growth was $4.84 \%$, so the elasticity of employment opportunities in Cianjur Regency in 2020 was 0.6585. So that the number of job opportunities in the Cianjur Regency in 2020 is estimated to be 354,201 people. Furthermore, by looking at the estimated growth of each economic sector (table 2), by comparing the growth in employment opportunities with economic growth in each industry, the elasticity of employment opportunities in each industry will be obtained.

Table 2 Growth of Gross Regional Domestic Product (GRDP) at 2000 Constant Prices and Cianjur Regency Sector, 2015-2020

\begin{tabular}{|c|c|c|c|c|c|c|}
\hline SECTOR & 2015 & 2016 & 2017 & 2018 & 2019 & 2020 \\
\hline Agriculture & 6,03 & 5,65 & 4,88 & 4,76 & 4,63 & 4,38 \\
\hline Mining & 8,26 & 8,52 & 9,05 & 9,15 & 9,23 & 9,50 \\
\hline Industry & 8,70 & 8,73 & 8,96 & 8,97 & 9,03 & 9,20 \\
\hline Electricity & 4,86 & 4,98 & 5,30 & 5,26 & 5,38 & 5,38 \\
\hline Building & 8,14 & 8,54 & 9,34 & 9,47 & 9,70 & 9,88 \\
\hline Trading & 9,97 & 9,60 & 9,76 & 11,01 & 10,06 & 10,96 \\
\hline Transport & 8,58 & 8,68 & 8,94 & 8,98 & 9,02 & 9,08 \\
\hline $\begin{array}{l}\text { Finance and } \\
\text { Banks }\end{array}$ & 11,43 & 12,08 & 13,37 & 13,59 & 13,78 & 14,01 \\
\hline Services & 8,65 & 8,85 & 9,25 & 9,32 & 9,39 & 9,52 \\
\hline PDRB & 7,36 & 8,06 & 7,96 & 7,76 & 7,62 & 7,73 \\
\hline
\end{tabular}

Source: Projection Figures

By knowing the magnitude of the employment opportunity elasticity of each economic sector in the Cianjur Regency, we can estimate the number of job opportunities in each financial sector. In 2015 employment opportunities in the agricultural industry were 237,568 people, mining 788 people, industry 29,448 people, electricity 470 , buildings 3,379 people, trade 44,807 people, transportation 15,302 , banks and other financial institutions as many as 320 people, and services as many as 22,142 people.

Policies and programs that will be carried out for workforce planning in the Province of Cianjur Regency are (a) the number of unemployed continues to increase, and the unemployment rate also continues to increase, especially in urban areas, (b) the number of unemployed people with a relatively high educational background (high school and above ) continues to increase, unemployment who finish university even shows a much more significant increase, (c) the percentage of underemployment shows a high enough figure, especially for women, more than half of the women who work in 2020 are included in the underemployment group and (d) the increasing number of workers who are self-employed or self-employed and unpaid family workers (Rakhmatullina, Sivaks \& Pecherskaya, 2019). This 
group can be categorized as informal workers.

\section{Employment Opportunity Expansion Policy}

To expand job opportunities by providing additional investment opportunities for businesses that are full of expanding job opportunities. This additional small-scale investment should be carried out in such a way that it can quickly and easily generate new business activities (Shan, Wang \& Hua, 2011). Efforts to simplify the process of granting credit are also significant as long as they benefit both parties. Likewise, efforts to expand employment opportunities in the trade sector should be carried out authentically (Scholz, 2017). Providing opportunities for the development of informal entrepreneurs need to be prioritized in the coming year (Tan, 1999).

The programs offered related to the expansion of job opportunities in Cianjur Regency in 2015-2020 are: (a) Empowerment programs for home industries and small industries, (b) Business capital assistance for informal sector workers, (c) Expansion of "off-farm" and off service employment, (d) investment cooperation (local and foreign) for employment expansion activities, (e) Empowerment and development (revitalization) of regional tourism products, (f) Promotion and marketing of tourism and (g) Promotion of agro-industrial business opportunities.

\section{Policy for Improving the Quality and Skills of Workers}

The implementation of the Policy for Improving the Quality and Skills of Workers can be applied through the following programs: (a) Training and apprenticeship programs for prospective workers for agribusiness and agroindustrial businesses, hotels, restaurants, and handicraft businesses, (b) Creating a partnership with various industries to apply the concept of "apprenticeship and training" (c) Development of work competency standards and a workforce competency certification system, and (d) Increasing the professionalism of coaching personnel and job training instructors as well as improving the facilities and infrastructure of job training institutions (Tang, Huang, Wang, Guo \& Yao, 2018).

\section{Manpower Development and Protection Policy}

Efforts to protect workers are, among others, by arranging a minimum wage determination that the calculation of the determination should be carried out without harming the workforce and carrying out sudden monitoring of the application of the minimum wage. Protection can be carried out by implementing the obligation of employers to provide labor rights in terms of insurance, work security, and equipment. The programs that are offered to realize the development and protection policies of workers are: (a) Production and marketing expansion program, (b) Determination of minimum wages and monitoring of its implementation, and (c) Increasing supervision, protection, and enforcement of applicable laws (Whited, Datta, Aiello \& Bursell, 2005). 


\section{CONCLUSION}

The low quality of the population is a barrier to the economic development of a region. This is mainly due to the low level of education and knowledge of the workforce. Therefore, to keep economic growth, especially in industry, it is necessary to have workers who have skills or the ability to read and write. The availability of a quality workforce will increase labor productivity so that if the labor productivity is high, the role of the crew as one of the factors of production in increasing national income is also high. In reality, the workforce has a very heterogeneous nature that can be seen in age, workability, health, education, gender, and expertise. Therefore, in planning for economic growth concerning the use of labor, it is necessary to have human resources planning in the Cianjur Hilir Regency, which is expected to be used as a source of information and a basis for the preparation of economic development planning, especially in Cianjur Regency.

\section{REFERENCES}

1. Abdurakhmanova, G., Shayusupova, N., Irmatova, A., \& Rustamov, D. (2020). The role of the digital economy in the development of the human capital market. Архив научных исследований, (25).

2. Asai, T., Hayashi, H., \& Minazuki, A. (2011). Fostering a "Monozukuri (manufacturing)" organization suitable for the 21st-century digital economy. New Knowledge in a New Era of Globalization, 199.

3. Bakry, S. H. (2004). Development of e-government: a STOPE view. International Journal of Network Management, 14(5), 339-350.

4. Bashehab, O. S. (2013). Status of a knowledge-based economy in the Kingdom of Saudi Arabia: An analysis. Journal of Social and Development Sciences, 4(6), 268-277.

5. Chao-he, R. O. N. G. (2006). The necessity of Economic Analysis Based on Transport Resources. Journal of Beijing Jiaotong University (Social Sciences Edition), 4.

6. ETIM, A., Ibietan, J., \& Abasilim, U. D. (2020). Manpower Planning and Organisational Effectiveness: Evidence from a Nigerian Public Bureau. Lead City Journal of the Social Sciences, 5(1).

7. Etoundi, R. A., Onana, F. S. M., Olle, G. D. O., \& Eteme, A. A. (2016). Development of the digital economy in Cameroon: challenges and perspectives. The Electronic Journal of Information Systems in Developing Countries, 76(1), 1-24.

8. Hojeghan, S. B., \& Esfangareh, A. N. (2011). Digital economy and tourism impacts, influences, and challenges. Procedia-Social and Behavioral Sciences, 19, 308-316.

9. Jin, Y., Gao, Y., Wang, P., Wang, J., \& Wang, L. (2019). Improved human resources planning based on traffic flow forecast using a historical queuing model. IEEE Access, 7, 125101-125112.

10. Li, F., Nucciarelli, A., Roden, S., \& Graham, G. (2016). How smart cities transform operations models: a new research agenda for operations 
management in the digital economy. Production Planning $\mathcal{E}$ Control, 27(6), 514528.

11. Li, X., Cao, J., Liu, Z., \& Luo, X. (2020). A sustainable business model based on digital twin platform network: The inspiration from hair's case study in China. Sustainability, 12(3), 936.

12. Malisuwan, U., Tiamnara, N., \& Suriyakrai, N. (2016). National digital economy plan to foster social and economic benefits in Thailand. Journal of Advances in Information Technology Vol, 7(2).

13. Manski, C. F. (2000). Economic analysis of social interactions. Journal of economic perspectives, 14(3), 115-136.

14. Mutula, S. M., \& Van Brakel, P. (2007). ICT skills readiness for the emerging global digital economy among small businesses in developing countries. Library Hi-Tech.

15. Palos-Sanchez, P. R., \& Correia, M. B. (2018). The collaborative economy based analysis of demand: Study of Airbnb case in Spain and Portugal. Journal of theoretical and applied electronic commerce research, 13(3), 85-98.

16. Parka, S. H., Yeonb, S. J., \& Kimc, S. W. (2006). Building a Dynamic Manpower Planning Model: Focused on the Information Security Manpower Policy of Korea. Unpublished Article. Lincoln: University of Nebraska.

17. Rahmana, M. P., \& Senusia, N. (2019). Exploring the Understanding, Role, and Participation of Small and Medium Enterprises (SMEs) On Digital Economy in Malaysia. Malaysian Journal of Consumer and Family Economics, 139-152.

18. Rakhmatullina, A. R., Sivaks, A. N., \& Pecherskaya, E. P. (2019, April). Assessment of Quality of Services of Public Transport in Digital Economy. In International Scientific Conference "Digital Transformation of the Economy: Challenges, Trends, New Opportunities" (pp. 269-280). Springer, Cham.

19. Scholz, T. (2017). Uber worked and underpaid: How workers are disrupting the digital economy. John Wiley \& Sons.

20. Shan, S., Wang, L., Wang, J., Hao, Y., \& Hua, F. (2011). Research on eGovernment evaluation model based on the principal component analysis. Information Technology and Management, 12(2), 173-185.

21. Tan, M. (1999). Creating the digital economy: Strategies and perspectives from Singapore. International Journal of Electronic Commerce, 3(3), 105-122.

22. Tang, Y., Huang, Y., Wang, H., Wang, C., Guo, Q., \& Yao, W. (2018). Framework for artificial intelligence analysis in large-scale power grids based on digital simulation. CSEE Journal of Power and Energy Systems, 4(4), 459-468.

23. Whited, J. D., Datta, S. K., Aiello, L. M., Aiello, L. P., Cavallerano, J. D., Conlin, P. R., ... \& Bursell, S. E. (2005). A modeled economic analysis of a digital teleophthalmology system as used by three federal healthcare agencies for detecting proliferative diabetic retinopathy. Telemedicine Journal $\mathcal{E} E$ Health, 11(6), 641-651. 